\title{
Spirodihydantoin Is a Minor Product of 5- Hydroxyisourate in Urate Oxidation
}

\author{
Hongbin $\mathrm{Yu}^{\mathrm{a}}$, Jacquin C. Niles ${ }^{\mathrm{a}}$, John S. Wishnok, and \\ Steven R. Tannenbaum ${ }^{a, b_{*}}$
}

\author{
Biological Engineering Division and Department of Chemistry, \\ Massachusetts Institute of Technology, 77 Massachusetts Avenue, \\ Room 56-731A, Cambridge, MA 02139 USA
}

srt@mit.edu

\section{Supporting Information}

\section{Contents:}

1. Experimental procedures

2. Mass spectra of allantoin, guanidinohydantoin, spiroiminodihydantoin, 2-methylspirodihydantoin, and 3-methylallantoin

3. HPLC chromatograms of oxidation of uric acid, 8-oxo-7,8-dihydroguanine, N9-methyluric acid, N7methyluric acid and decomposition of 5-chloro-N7-methylisouric acid

4. LC-MS chromatograms of detection of spirodihydantoin with labeled spirodihydantoin as the internal standard

5. Mass spectra of ${ }^{18} \mathrm{O}$-labeled spirodihydantoin, spirodihydantoin and $2-{ }^{13} \mathrm{C}-1,3-{ }^{15} \mathrm{~N}_{2}$ - spirodihydantoin

6. ${ }^{13} \mathrm{C}-\mathrm{NMR}$ of spirodihydantoin and 1-methylspirodihydantoin

7. Scheme 1: ${ }^{18} \mathrm{O}$-labeling experiments and decomposition of 5-chloro-N7-methylisouric acid

8. Scheme 2: decomposition of 5-OH-isourate and 5-OH-80xo-7,8-dihydroguanine

9. Physico-chemical properties of stable analogs of 5-OH-isourate and 5-OH-8-oxo-7,8-dihydroguanine 10. References 


\section{Experimental Procedures:}

General Information: All reagents were of commercial quality and used as received. A ThermosilKeystone hypercarb column $(150 \times 3 \mathrm{~mm}, 5 \mu \mathrm{m})$ was used for most HPLC and LC-MS analyses on Agilent 1100 Series HPLC and LC/MSD systems, respectively. In a typical LC-MS analysis, the mobile phase consisted of $0.4 \%$ formic acid in water (A) and $0.4 \%$ formic acid in acetonitrile (B) with $0-3 \%$ B over $10 \mathrm{~min}$ at a flow of $0.2 \mathrm{~mL} / \mathrm{min}$. Selective ion monitoring (SIM) at 185.1/188.1 (positive ion mode) or 183.1/186.1 (negative ion mode) was used to detect the labeled and unlabeled spirodihydantoin. In a typical HPLC analysis, the mobile phase consisted of ammonium bicarbonate $(50 \mathrm{mM}, \mathrm{pH} 7.4)(\mathrm{A})$ and acetonitrile (B) with $0-20 \%$ B over $30 \mathrm{~min}$ at a flow rate of $0.3 \mathrm{~mL} / \mathrm{min}$. Uric acid and allantoin were quantitated by HPLC-UV using external standards. Spirodihydantoin was quantitated by isotope-dilution mass spectrometry in positive or negative ion mode using labeled spirodihydantoin as the internal standard. High-resolution FT-MS analyses were conducted on a Bruker FTMS. ESI-MS analyses were conducted on an Agilent ESI-TOF MS. Allantoin, spirodihydantoin, guanidinohydantoin and spiroiminodihydantoin bases and their corresponding ${ }^{18} \mathrm{O}$-labeled compounds, 1-methylallantoin, 3methylallantoin, and 1-methylspirodihydantoin were all dissolved in water. The ESI-TOF MS analyses were conducted on the hypercarb column. The mobile phase consisted of $0.4 \%$ formic acid in water (A) and $0.4 \%$ formic acid in acetonitrile $(\mathrm{B})$ with a gradient of $0-9 \% \mathrm{~B}$ over $30 \mathrm{~min}$ at a flow rate of $0.2 \mathrm{~mL} / \mathrm{min}$. The NMR experiments were conducted on a Varian $500 \mathrm{MHz}$ instrument. Both spirodihydantoin and 1methylspirodihydantoin were dissolved in $\mathrm{D}_{6}$-DMSO and the ${ }^{13} \mathrm{C}-\mathrm{NMR}$ data were collected overnight.

Synthesis of Spirodihydantoin and $2-{ }^{13} \mathrm{C}-1,3-{ }^{15} \mathrm{~N}_{2}$-Spirodihydantoin. The synthesis of spirodihydantoin ( $\mathrm{Spd}$ ) was a modification of Poje's procedure(1). Acetonitrile was added to the mixture of anhydrous 4-hydroxy-2,5-dioxo-4-imidazolidinecarboxyureide and trifluoroacetic anhydride. The resulting mixture was heated at $75^{\circ} \mathrm{C}$ for $10 \mathrm{~min}$. Solvents were evaporated in vacuo to afford a viscous yellow residue, to which methanol $(20 \mathrm{~mL})$ was added to give a precipitate. The precipitate was recrystallized from water as a colorless solid (ESI-MS: $185.1[\mathrm{M}+\mathrm{H}]^{+} ; 183.1[\mathrm{M}-\mathrm{H}]$; $140.1[\mathrm{M}-\mathrm{H}-\mathrm{NHCO}]$; FT-MS (negative ion mode): theoretical mass of $[\mathrm{M}-\mathrm{H}]$ : 183.0149 ; actual mass: $183.0152 ;{ }^{13} \mathrm{C}$ NMR $\left(\mathrm{D}_{6}-\mathrm{DMSO}\right): \delta$ 
169.6, $155.9,83.0$ and $76.2 \mathrm{ppm})$. The synthesis of $2-{ }^{13} \mathrm{C}-1,3-{ }^{15} \mathrm{~N}_{2}$-spirodihydantoin was similar to that of spirodihydantoin except that ${ }^{13} \mathrm{C},{ }^{15} \mathrm{~N}_{2}$-labeled urea was used (FT-MS: theoretical mass: 186.0149; actual mass: 186.0123 [M-H]; ESI-MS: $188.1[\mathrm{M}+\mathrm{H}]^{+} ; 186.1[\mathrm{M}-\mathrm{H}]$; $143.1[\mathrm{M}-\mathrm{H}-\mathrm{NHCO}], 142.1\left[\mathrm{M}-\mathrm{H}-{ }^{15} \mathrm{NHCO}\right]$, and $\left.141.1\left[\mathrm{M}-\mathrm{H}-{ }^{15} \mathrm{NH}^{13} \mathrm{CO}\right]\right)$. Both spiro compounds were further purified by HPLC on a $4.6 \times 250 \mathrm{~mm}$ Zorbax Eclipse XDB C8 column with $100 \%$ water as mobile phase at a flow rate of $1.0 \mathrm{~mL} / \mathrm{min}$. Retention times for both the labeled and unlabeled spiro compounds were $2.8 \mathrm{~min}$.

Oxidation of Uric Acid by 2 equivalents of $\mathrm{Na}_{2} \mathrm{IrCl} \mathrm{Cl}_{6}$ at Various $\mathrm{pH}$. Uric acid (901 $\left.\mu \mathrm{M}\right)$ and labeled Spd $(0.9 \mu \mathrm{M})$ were dissolved in potassium phosphate $(\mathrm{KPi})$ buffers $(0.1 \mathrm{M}, \mathrm{pH}$ at $6.7,7.4,8.0,9.5$, 10.2, 11.2 and 12.2). $\mathrm{Na}_{2} \mathrm{ICl}_{6}(1.8 \mathrm{mM})$ was added (2) and the resulting mixture stirred at room temperature for $30 \mathrm{~min}$. Each oxidation was carried out in duplicates with control experiments where no $\mathrm{Na}_{2} \mathrm{IrCl}_{6}$ was added.

Dose Response of Oxidation of Uric Acid by $\mathrm{Na}_{2} \mathrm{IrCl}_{6}$ at $\mathrm{pH}$ 8.0. Uric acid $(919 \mu \mathrm{M})$ and labeled Spd $(0.9 \mu \mathrm{M})$ were dissolved in $\mathrm{KPi}$ buffer $(0.1 \mathrm{M}, \mathrm{pH} 8.0) . \mathrm{Na}_{2} \operatorname{IrCl} l_{6}(0.2,0.5,1,2,5,10$ or 20 equivalents relative to uric acid) was added and the resulting mixture stirred at room temperature for 30 min. Each oxidation was carried out in duplicates with control experiments where no $\mathrm{Na}_{2} \mathrm{ICl}_{6}$ was added.

Oxidation of Uric Acid by 2 equivalents of $\mathrm{Na}_{2} \mathrm{ICl}_{6}$ at Various Temperatures. Uric acid (930 $\mu \mathrm{M})$, labeled Spd $(1.4 \mu \mathrm{M})$, and $\mathrm{Na}_{2} \mid \mathrm{ICl}_{6}(1.9 \mathrm{mM})$ were held in $\mathrm{KPi}$ buffer $(0.1 \mathrm{M}, \mathrm{pH} 7.4)$ at $0{ }^{\circ} \mathrm{C}, 24,50$, 62 and $84{ }^{\circ} \mathrm{C}$ for 30 min with stirring. Each oxidation was carried out in duplicates with control experiments where no $\mathrm{Na}_{2} \mathrm{IrCl}_{6}$ was added.

Dose Response of Oxidation of Uric Acid by Peroxynitrite. Uric acid (925 $\mu \mathrm{M})$ and labeled Spd $(0.7 \mu \mathrm{M})$ were dissolved in a buffer containing $\mathrm{KPi}(150 \mathrm{mM})$ and sodium bicarbonate $(25 \mathrm{mM})(\mathrm{pH}$ 7.2) and varying equivalents of peroxynitrite relative to uric acid $(0.2,0.5,1$ and 2$)$ were added to separate reactions in bolus fashion. Uric acid concentration was reduced to $171 \mu \mathrm{M}$ when 10 and 20 equivalents of peroxynitrite were applied. Each oxidation was carried out in duplicates with control experiments where no peroxynitrite was added. 
Oxidation of Uric Acid by Uricase $/ \mathrm{O}_{2}$. Urate oxidase (1 unit) was added to an oxygenated solution of uric acid $(918 \mu \mathrm{M})$ and labeled Spd $(0.7 \mu \mathrm{M})$ (in $\mathrm{pH} 7.4 \mathrm{KPi}$ buffer) $(3)$. $\mathrm{O}_{2}$ was gently bubbled through the mixture for $15 \mathrm{~min}$. The reaction mixture was applied to Amicon YM-10 centrifugal spin columns and the filtrate was concentrated by freeze-drying for the analysis of Spd.

Oxidation of Uric Acid by Horseradish Peroxidase $\mathrm{H}_{2} \mathrm{O}_{2}$ with or without Presence of $\mathrm{NO}_{2}$. Horseradish peroxidase $(3.9 \mu \mathrm{M})$, uric acid $(753 \mu \mathrm{M})$, labeled Spd $(0.9 \mu \mathrm{M})$, DTPA $(99 \mu \mathrm{M})$, and $\mathrm{NaNO}_{2}$ (10.8 mM) were gently mixed in KPi buffer $\left(0.1 \mathrm{M}\right.$, pH 7.4). $\mathrm{H}_{2} \mathrm{O}_{2}(12.7 \mathrm{mM})$ was added to the mixture to initiate the oxidation(4). The reaction mixture was stirred at room temperature for $8 \mathrm{~h}$ and applied to Amicon YM-10 centrifugal spin columns. The filtrate was concentrated for the analysis of uric acid, allantoin and Spd. For the oxidation without the presence of $\mathrm{NO}_{2}$, an equivalent volume of water was added instead of the nitrite solution.

Oxidation of Uric Acid by Myeloperoxidase $/ \mathrm{H}_{2} \mathrm{O}_{2}$ with or without Presence of $\mathrm{NO}_{2}$. Myeloperoxidase $(0.02 \mu \mathrm{M})$, uric acid $(733 \mu \mathrm{M})$, labeled Spd $(0.8 \mu \mathrm{M})$, DTPA $(94.3 \mu \mathrm{M})$, and $\mathrm{NaNO}_{2}(10.3$ $\mathrm{mM}$ ) were gently mixed. $\mathrm{H}_{2} \mathrm{O}_{2}(0.06 \mathrm{mM})$ was added to the mixture to initiate the oxidation(4). The reaction mixture stirred at room temperature for $8 \mathrm{~h}$ and was applied to Amicon YM-10 centrifugal spin columns. The filtrate was concentrated for the analysis of uric acid, allantoin and Spd. For the oxidation without $\mathrm{NO}_{2}$, an equivalent volume of water was added instead of the nitrite solution.

Synthesis of 4-Hydroxy-1-methyl-2,5-dioxo-4-imidazolidinecarboxyureide and 1Methylspirodihydantoin. The synthesis of 4-hydroxy-1-methyl-2,5-dioxo-4-imidazolidinecarboxyureide was a modification of Poje's procedure (1). To a warm aqueous alloxan solution (1.7 M), methylurea (2.4 M) was added. The resulting solution was kept at $70{ }^{\circ} \mathrm{C}$ for 20 min to give a precipitate, which was filtered and recrystallized from ethanol to afford light pink crystals of 4-hydroxy-1-methyl-2,5-dioxo-4imidazolidinecarboxyureide (52\%) (ESI-MS: $\left.217.2[\mathrm{M}+\mathrm{H}]^{+}, 215.2[\mathrm{M}-\mathrm{H}]\right)$. The synthesis of 1methylspirodihydantoin was similar to that of spirodihydantoin except that a 2-hour heating time at $80{ }^{\circ} \mathrm{C}$ was employed. 1-Methylspirodihydantoin was purified by HPLC with a Zorbax Eclipse XDB C8 column (mobile phase consisting of water and acetonitrile with acetonitrile from $0-3.5 \%$ over $7 \mathrm{~min}$ at a flow rate 
of $1.0 \mathrm{~mL} / \mathrm{min}$ ). HPLC fractions between 5 and $7 \mathrm{~min}$ were collected and freeze-dried to afford pure 1methylspirodihydantoin (ESI-MS: $197.1[\mathrm{M}-\mathrm{H}]$ and $154.1[\mathrm{M}-\mathrm{H}-\mathrm{NHCO}], 199.1[\mathrm{M}+\mathrm{H}]^{+}$and $\left.216.1\left[\mathrm{M}+\mathrm{NH}_{4}\right]^{+}\right)$; FT-MS: theoretical mass: $197.0305[\mathrm{M}-\mathrm{H}]$; actual mass: $197.0309 ;{ }^{13} \mathrm{C}-\mathrm{NMR}\left(\mathrm{D}_{6}-\mathrm{DMSO}\right): \delta 169.4,168.2$, $155.9,155.5,75.2$ and $24.7 \mathrm{ppm})$.

Oxidation of N9-Methyluric Acid by 2 equivalents of $\mathrm{Na}_{2} \mathrm{IrCl}_{6^{*}}$ To an $\mathrm{N9}$-methyluric acid solution $(954 \mu \mathrm{M})$ (in $0.1 \mathrm{M}, \mathrm{pH} 7.4 \mathrm{KPi}$ buffer), $\mathrm{Na}_{2} \mathrm{IrCl}_{6}(1.9 \mathrm{mM})$ was added. The resulting solution was stirred at room temperature for $48 \mathrm{~h}$. To an aliquot of the reaction mixture, 1-methylspirodihydantoin (82 $\mu \mathrm{M})$ was added. In another aliquot of the reaction mixture an equivalent volume of $\mathrm{KPi}$ buffer $(\mathrm{pH} 7.4,0.1$ M) was added as a control. Both the spiked solution and the control solution were analyzed by HPLC on the hypercarb column. HPLC conditions were as above except that the acetonitrile gradient was from 0$60 \%$ over $20 \mathrm{~min}$. 1-Methylspirodihydantoin and 1-methylallantoin were eluted after 8.5 and $9.8 \mathrm{~min}$, respectively.

Synthesis and Purification of Spiroiminodihydantoin and Guanidinohydantoin Bases. To a $\mathrm{Na}_{2} \mathrm{IrCl}_{6}$ solution (7.4 mM) (in 0.1 M, in pH 11.2, 9.2, 7.3 and 5.3 KPi buffer, respectively), 8-oxo-7,8dihydroguanine was added to saturation. The resulting suspension was stirred at room temperature for 48 $\mathrm{h}$ then filtered. The $\mathrm{pH}$ of the filtrate was adjusted to 7.5 using either phosphoric acid or sodium hydroxide, and the products in these solutions were analyzed by HPLC (on a $4.6 \times 250 \mathrm{~mm}$ LC-18-DB column, Supelco). The mobile phase consisted of $1 \%$ acetonitrile and $99 \%$ water at a flow rate of 1.0 $\mathrm{mL} / \mathrm{min}$. Spiroiminodihydantoin and guanidinohydantoin bases eluted after $3.5 \mathrm{~min}$ and $4.7 \mathrm{~min}$, respectively. The remaining filtrate was freeze-dried and purified by silica gel flash chromatography. Products were eluted with $100 \mathrm{~mL}$ 1:1 methanol/ethyl acetate. Guanidinohydantoin (the major product at $\mathrm{pH}$ 5.3) and spiroiminodihydantoin (the major product at $\mathrm{pH}$ 11.2) were further purified by HPLC using the LC-18-DB column as before.

Oxidation of 8-oxo-7,8-dihydroguanine with 2 equivalents of $\mathrm{Na}_{2} \mathrm{IrCl}_{6}$ at Different $\mathrm{pH}$. To an 8-oxo-7,8-dihydroguanine solution $\left(23.4 \mu \mathrm{M}\right.$ ) (in $0.1 \mathrm{M} \mathrm{KPi}$ buffer with $\mathrm{pH} 9.5,10.2$ or 11.2), $\mathrm{Na}_{2} \operatorname{IrCl}_{6}(46.8$ $\mu \mathrm{M})$ was added. The resulting solution was stirred at room temperature for $6 \mathrm{~h}$, then the $\mathrm{pH}$ of the solution 
was adjusted to 6.9 using $85 \%$ phosphoric acid. An aliquot of the acidified solution was concentrated by freeze-drying for the quantitation of spiroiminodihydantoin and guanidinohydantoin bases.

Oxidation of Allantoin by 10 equivalents of $\mathrm{Na}_{2} \mathrm{IrCl}_{6}$ or 10 equivalents of Peroxynitrite. To an allantoin solution $(0.81 \mathrm{mM})(0.1 \mathrm{M}, \mathrm{pH} 7.4 \mathrm{KPi}$ buffer $), \mathrm{Na}_{2} \mathrm{IrCl}_{6}(8.1 \mathrm{mM})$ was added. For reactions with peroxynitrite $(7 \mathrm{mM})$, allantoin $(0.7 \mathrm{mM})$ was dissolved in a buffer containing $\mathrm{KPi}(150 \mathrm{mM})$ and sodium bicarbonate $(25 \mathrm{mM})(\mathrm{pH} 7.2)$ and peroxynitrite was added in bolus fashion. The reactions were stirred at room temperature for $4 \mathrm{~h}$. Remaining allantoin was quantitated by HPLC according to the typical procedure in the general information.

Decomposition of Allantoin in KPi Buffer (pH 11.2 or 12.2). Allantoin (0.1 mM) was dissolved in KPi buffer (0.1 M, pH 11.2 or 12.2). The decomposition of allantoin with time was monitored by HPLC according to the procedure descried in the general information.

Oxidation of N7-Methyluric Acid by 2 equivalents of $\mathrm{Na}_{2} \mathrm{IrCl}_{6^{*}}$ To N7-methyluric acid (454 $\left.\mu \mathrm{M}\right)$ (in $0.1 \mathrm{M}, \quad \mathrm{pH} \quad 7.4 \mathrm{KPi}$ buffer), $\mathrm{Na}_{2} \mathrm{IrCl}_{6}(1.9 \mathrm{mM})$ was added. 1-Methylallantoin and 1methylspirodihydantoin were isolated by HPLC on a Hypercarb column using acetonitrile (B) and $10 \mathrm{mM}$ ammonium acetate (A) as mobile phases. A gradient from $0-30 \%$ B over 20 min and a flow rate of 0.3 $\mathrm{mL} / \mathrm{min}$ were used. 1-Methylspirodihydantoin and 1-methylallantoin containing fractions were collected between 7.5 -11.5 min and 11.5-15 min, respectively.

Synthesis and Decomposition of 5-Chloro-N7-methylisouric Acid. 5-Chloro-N7methylisouric acid was prepared according to literature(5). Briefly, N7-methyluric acid (23 mg) was suspended in $15 \mathrm{~mL}$ of dry chloroform. The suspension was cooled in an ice-bath while $\mathrm{Cl}_{2}$ gas was bubbled through for $30 \mathrm{~min}$. The green colored mixture was stirred at $0{ }^{\circ} \mathrm{C}$ for $3 \mathrm{~h}$. Chloroform was evaporated to afford a solid residue. The solid $(2 \mathrm{mg})$ was dissolved in $10 \mathrm{~mL}$ of $\mathrm{KPi}$ buffer $(0.1 \mathrm{M}, \mathrm{pH} 7.4)$ and stirred at room temperature for $1 \mathrm{~h}$. 3-Methylallantoin, 2-methylspirodihydantoin and remaining N7methyluric acid were isolated by HPLC on the hypercarb column. In the control experiments where N7methyluric acid was dissolved in the same buffer, no 2-methylspirodihydantoin or 3-methylallantoin was detected. 
Oxidation of 8-oxo-7,8-dihydroguanine by 2 equivalents $\mathrm{Na}_{2} \mathrm{IrCl}_{6}$ in $\mathrm{H}_{2}^{16} \mathrm{O}$ and $\mathrm{H}_{2}^{18} \mathrm{O}$. 8-0xo7,8-dihydroguanine (233 uM) was dissolved in KPi buffer $(0.1 \mathrm{M}, \mathrm{pH} 9.5)$. An aliquot $(1.5 \mathrm{~mL})$ of the solution was freeze-dried and reconstituted with $1.5 \mathrm{~mL}$ of $\mathrm{H}_{2}^{18} \mathrm{O}$ (isotopic purity > 95\%). $\mathrm{Na}_{2} \mathrm{IrCl}_{6}(167 \mathrm{uL}$ of $4.2 \mathrm{mM}$ in $\mathrm{H}_{2}^{18} \mathrm{O}$ water, 2 equivalents) was then added. The oxidation in $\mathrm{H}_{2}^{16} \mathrm{O}$ was carried out similarly. The resulting mixture was stirred at room temperature for $6 \mathrm{~h}$. Guanidinohydantoin and spiroiminodihydantoin bases were purified using the Hypercarb column. The mobile phases were acetonitrile (B) and ammonium acetate $(10 \mathrm{mM}, \mathrm{pH} 7)(\mathrm{A})$ and a gradient from 0-20 B\% over $30 \mathrm{~min}$ at a flow rate of $0.3 \mathrm{~mL} / \mathrm{min}$ were used. The retention times of guanidinohydantoin and spiroiminodihydantoin bases were 7.6 and $13.5 \mathrm{~min}$, respectively. The HPLC fractions containing both compounds were collected and analyzed by LC-ESI-TOF MS.

Oxidation of Uric Acid by 2 equivalents of $\mathrm{Na}_{2} \mathrm{IrCl}_{6}$ in $\boldsymbol{H}_{2}^{16} \mathrm{O}$ and $\boldsymbol{H}_{2}^{18} \mathrm{O}$. Uric acid (1 mM) was dissolved in KPi buffer (0.1 M, pH 9.5). An aliquot of the uric acid solution (0.6 mL) was freeze-dried and reconstituted with $0.6 \mathrm{~mL}$ of $\mathrm{H}_{2}^{18} \mathrm{O}$. The solution was mixed with $2-{ }^{13} \mathrm{C}-1,3-{ }^{15} \mathrm{~N}_{2}$-labeled Spd (3.3 nmol) and Spd $(5.4 \mathrm{nmol})$. To the solution, $\mathrm{Na}_{2} \mathrm{IrCl}_{6}\left(28.2 \mathrm{uL}\right.$ of $4.2 \mathrm{mM}$ in $\mathrm{H}_{2}{ }^{18} \mathrm{O}, 2$ equivalents) was added. The mixture was stirred at room temperature for $1 \mathrm{~h}$. The oxidation in $\mathrm{H}_{2}^{16} \mathrm{O}$ was carried out similarly, but with the addition of $3.3 \mathrm{nmol}$ of labeled Spd only. Spd and allantoin were purified by the Hypercarb column as described immediately above. The retention times of Spd and allantoin were at 9.0 and $13.3 \mathrm{~min}$, respectively. The HPLC fractions containing allantoin and Spd were collected, freeze-dried and analyzed by LC-ESI-TOF MS.

Stability of Spirodihydantoin under Alkaline pH. Spirodihydantoin (0.27 mM) was dissolved in $\mathrm{KPi}$ buffer (50 mM, pH 12.2). Aliquots of the solution were analyzed using HPLC on the hypercarb column at different time points (at $0 \mathrm{~min}, 30 \mathrm{~min}$, and $4 \mathrm{~h}$ ). The mobile phase consisted of $10 \mathrm{mM} \mathrm{NH}_{4} \mathrm{OAc}(\mathrm{A})$ and acetonitrile (B) with a gradient of $0-28 \%$ B over $40 \mathrm{~min}$ at a flow rate of $0.2 \mathrm{~mL} / \mathrm{min}$. Spirodihydantoin was eluted after $11 \mathrm{~min}$. No significant degradation of spirodihydantoin was observed in 4 hours.

Oxidation of 8-OxodG by $\mathrm{Na}_{2} \mathrm{ICl}_{6}$ at $\mathrm{pH}$ 9.5. 8-OxodG (1.8 mM) was dissolved in KPi buffer (50 mM, pH 9.5). To the solution $\mathrm{Na}_{2} \mathrm{IrCl}_{6}(3.6 \mathrm{mM})$ was added to completely oxidize 8-oxodG. The reaction mixture was analyzed using HPLC on the hypercarb column. The mobile phase consisted of 10 
$\mathrm{mM} \mathrm{NH} \mathrm{OH}_{4} \mathrm{OAc}(\mathrm{A})$ and acetonitrile (B) with a gradient of $0-28 \% \mathrm{~B}$ over $40 \mathrm{~min}$ at a flow rate of $0.2 \mathrm{~mL} / \mathrm{min}$. Spiroiminodihydantoin nucleoside was eluted after 12.0 and $13.6 \mathrm{~min}$. No guanidinohydantoin nucleoside was observed.

Mass Spectra of Allantoin, Guanidinohydantoin, Spiroiminodihydantoin, 2Methylspirodihydantoin, and 3-Methylallantoin

Allantoin from oxidation of uric acid in $\mathrm{H}_{2} \mathrm{O}$

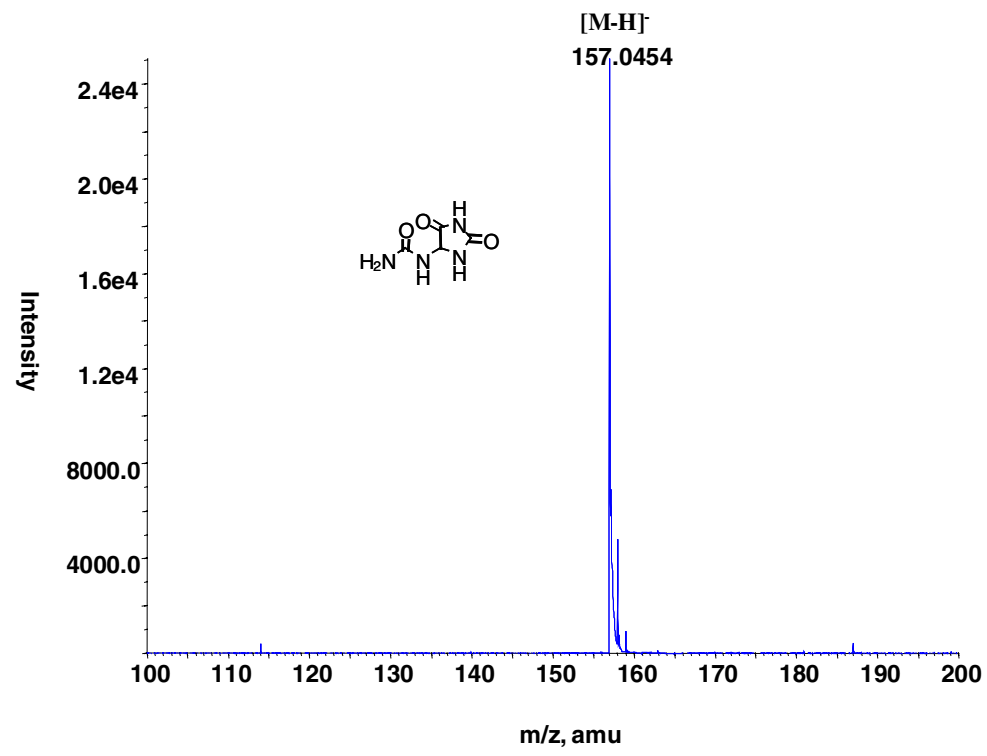

Allantoin from oxidation of uric acid in $\mathrm{H}_{2}{ }^{18} \mathrm{O}$

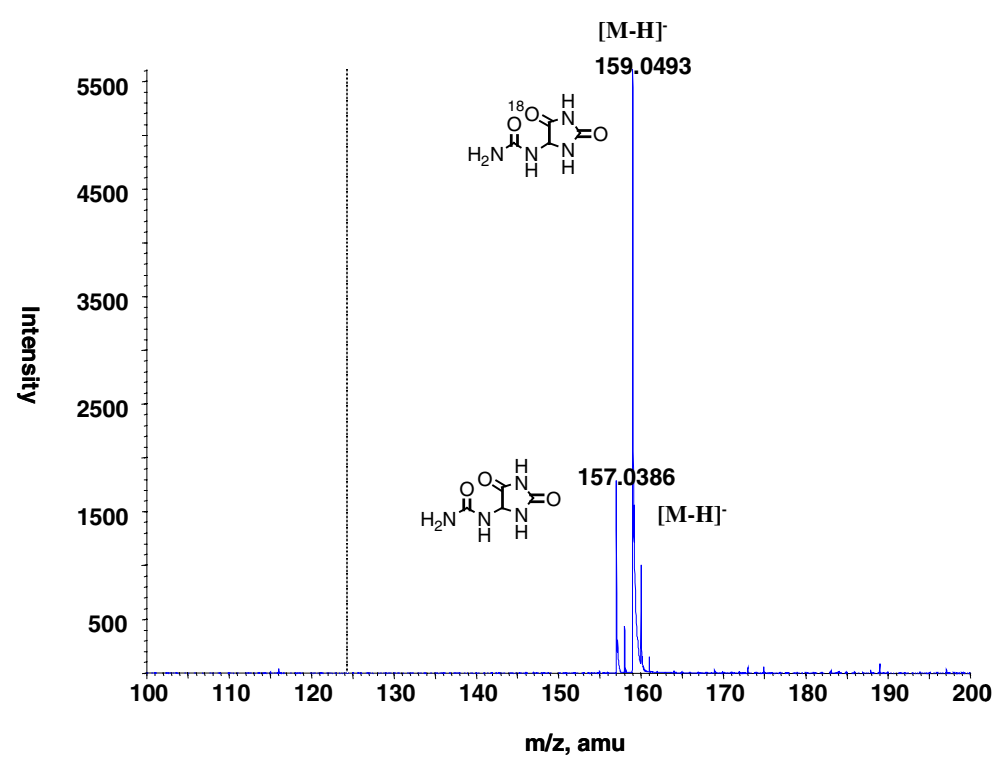


Guanidinohydantoin base from the oxidation of 8-oxo-7,8-dihydroguanine in $\mathrm{H}_{2} \mathrm{O}$

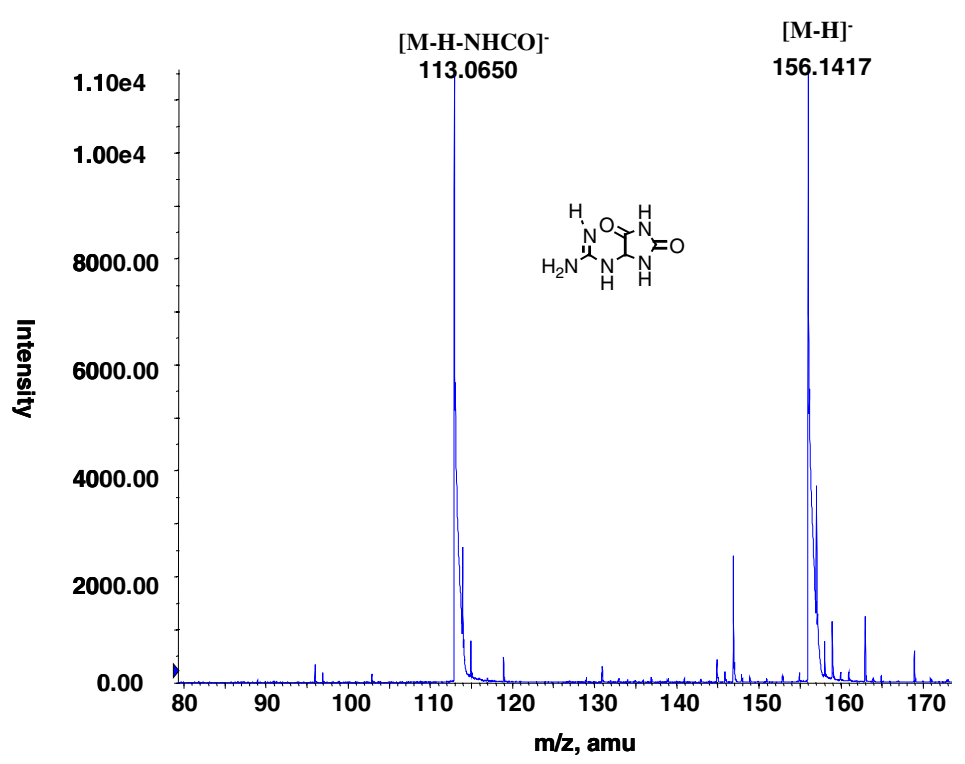

Guanidinohydantoin base from the oxidation of 8-oxo-7,8-dihydroguanine in $\mathrm{H}_{2}^{18} \mathrm{O}$

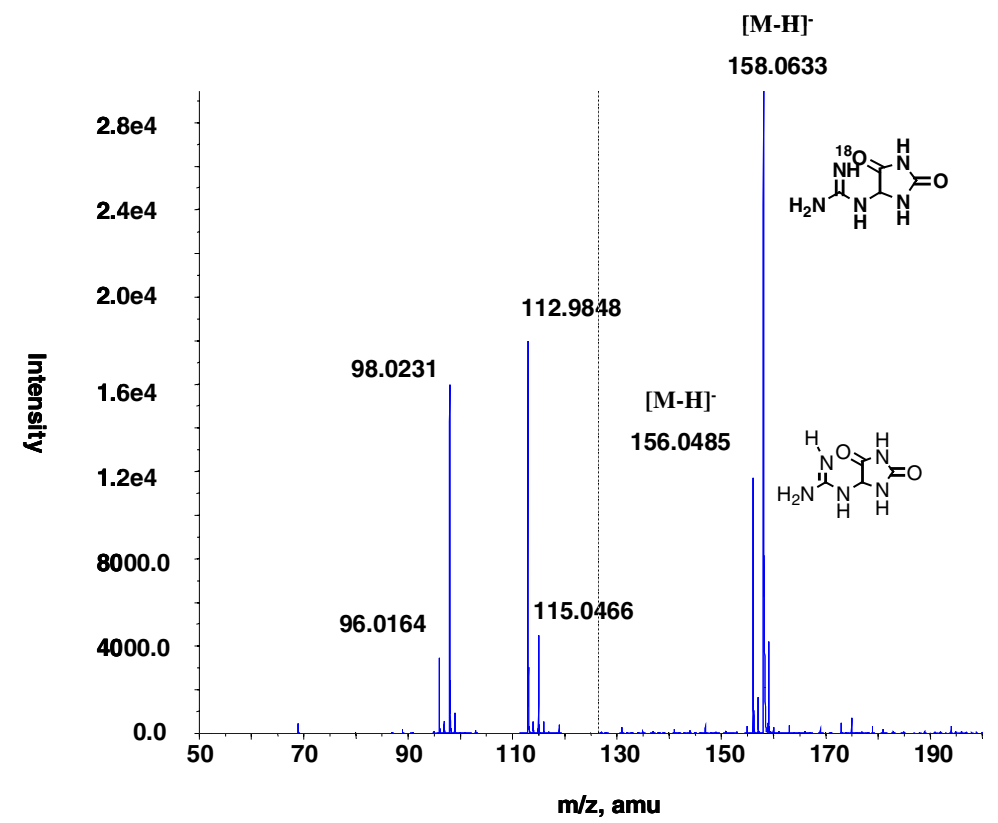


Spiroiminodihydantoin base from oxidation of 8-oxo-7,8-dihydroguanine in $\mathrm{H}_{2} \mathrm{O}$

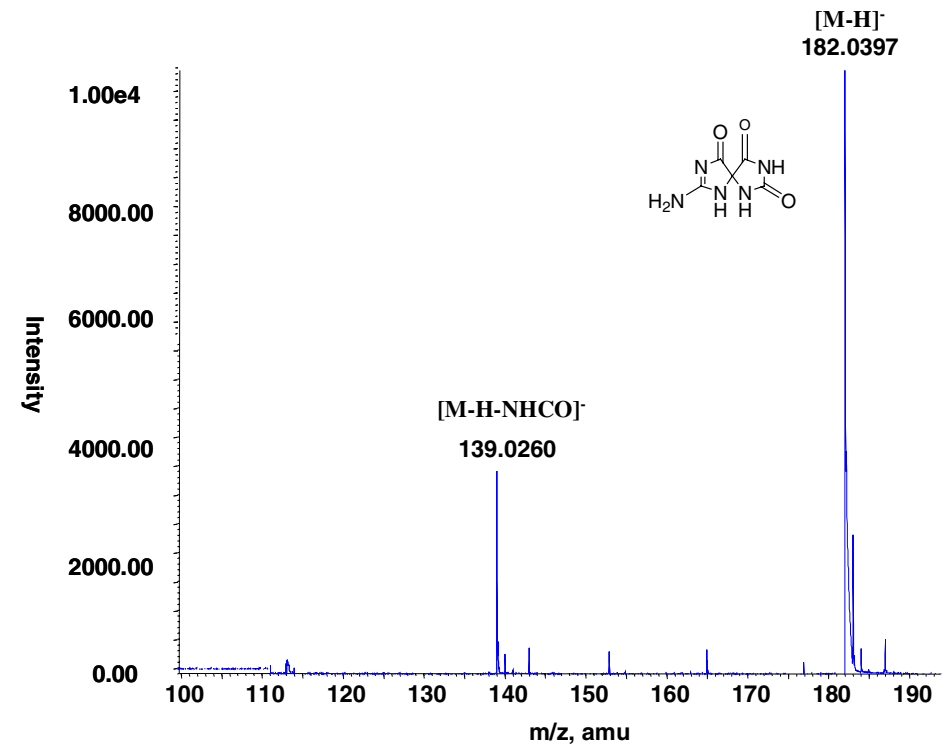

Spiroiminodihydantoin base from oxidation of 8-oxo-7,8-dihydroguanine in $\mathrm{H}_{2}{ }^{18} \mathrm{O}$

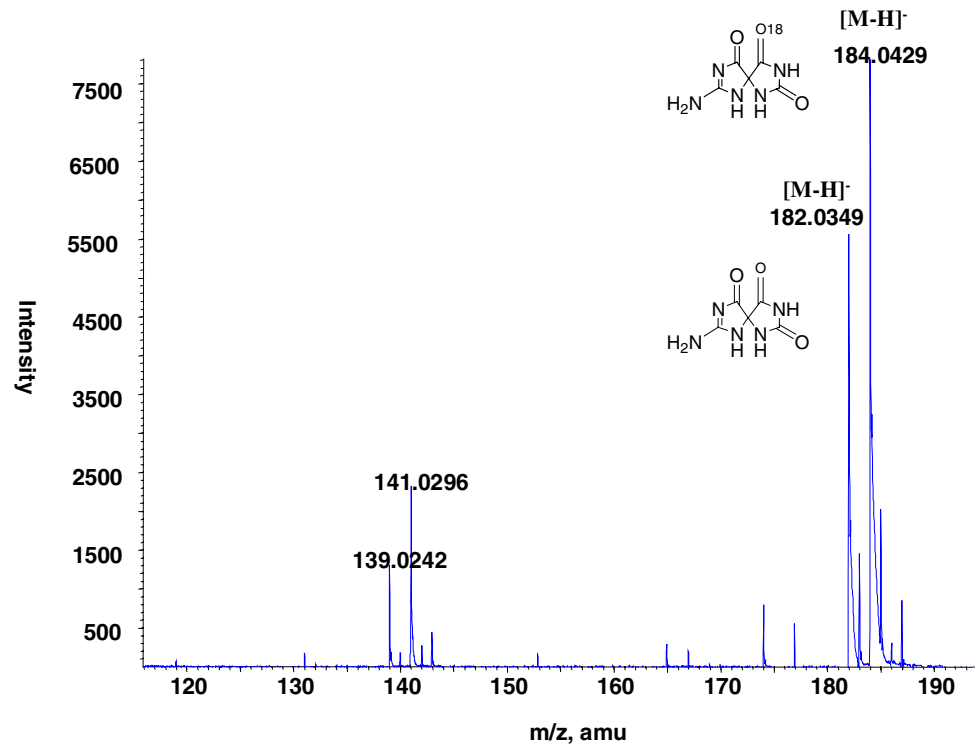


3-Methylallantoin from oxidation of N7-methyluric acid or decomposition of 5-Cl-N7-methylisouric acid

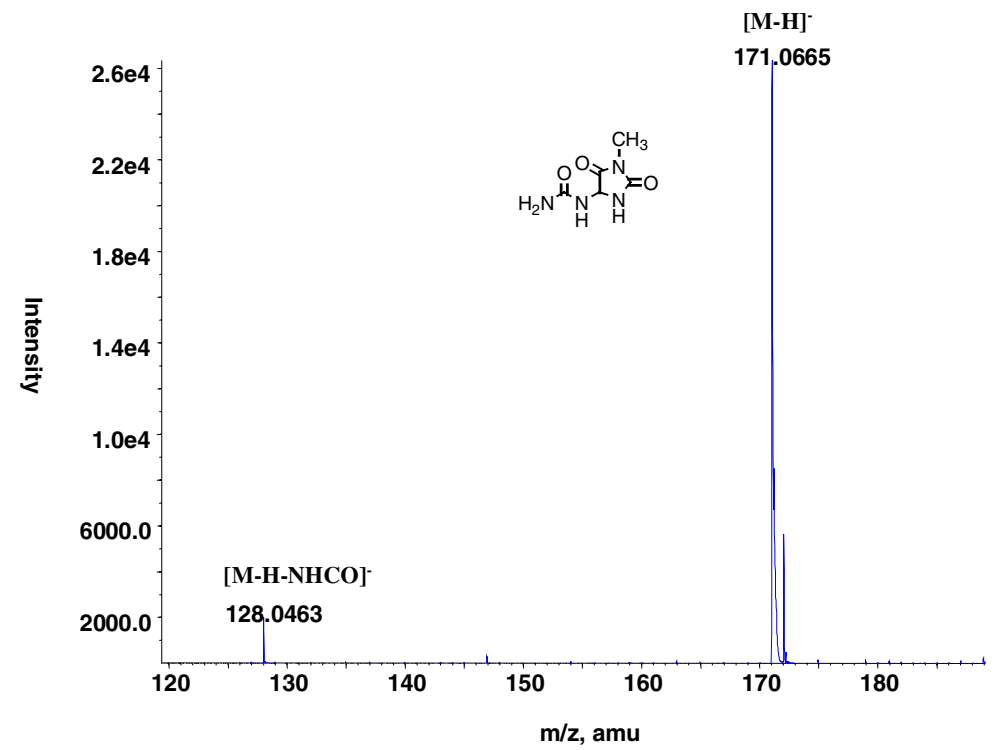

2-Methylspirodihydantoin from oxidation of N7-methyluric acid or decomposition of 5-Cl-N7methylisouric acid

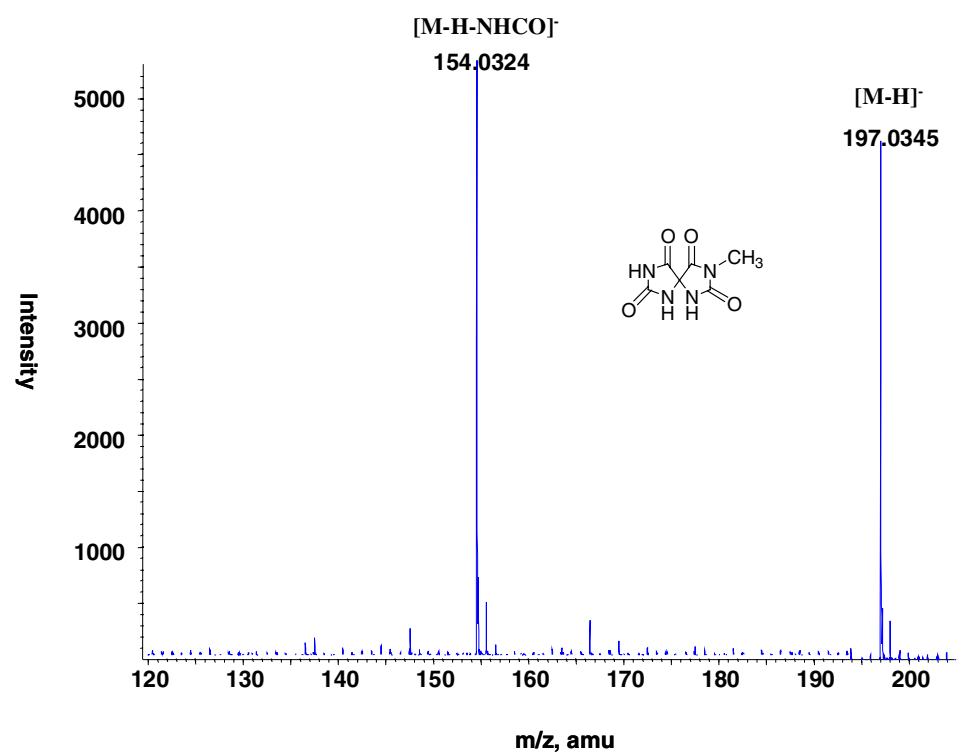


HPLC Chromatograms of Oxidation of Uric Acid, 8-0xo-7,8-dihydroguanine, N9-methyluric acid, N7-methyluric acid and Decomposition of 5-Chloro-N7-methylisouric Acid

\section{Oxidation of Uric Acid}

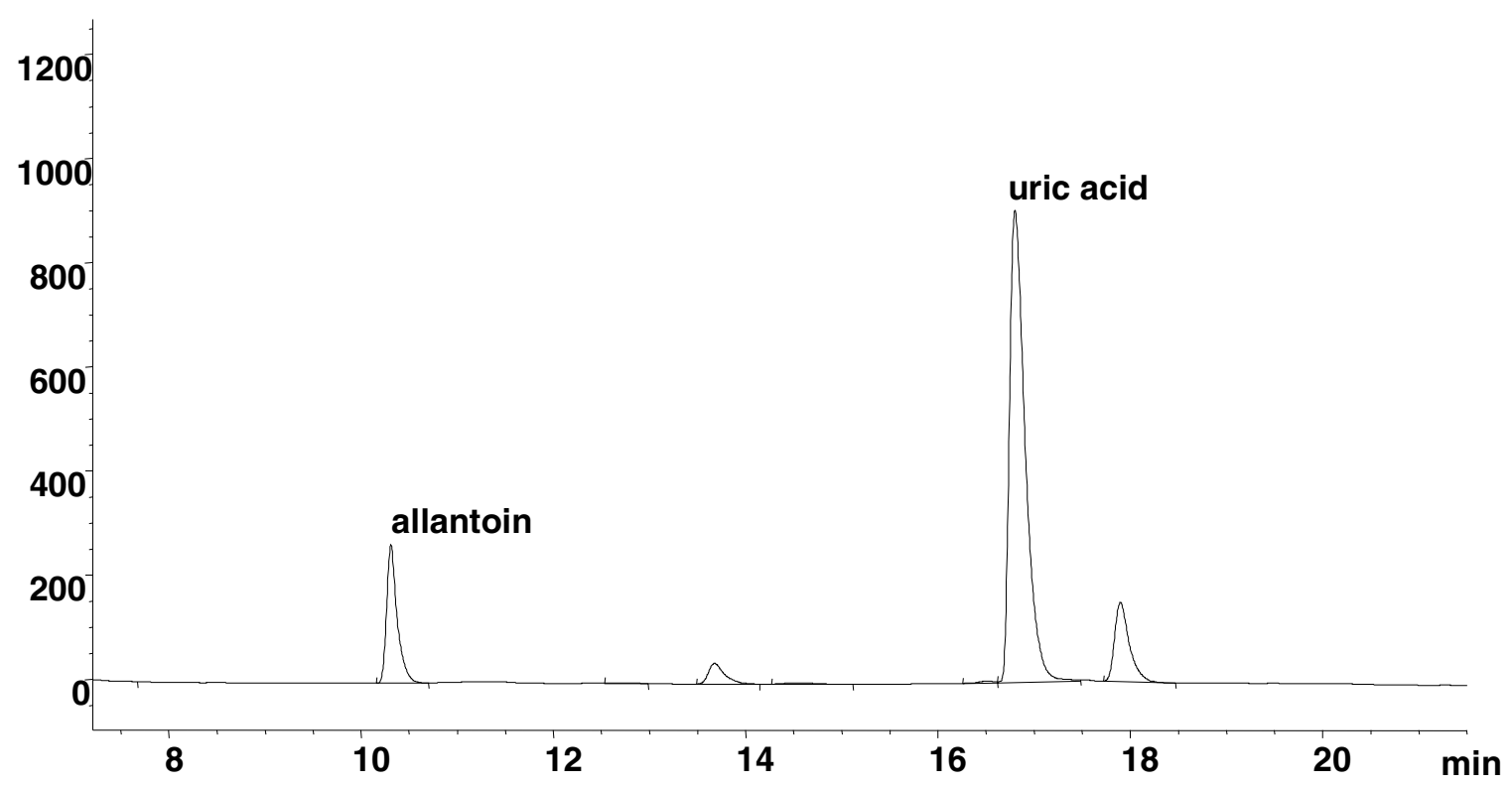

Oxidation of 8-oxo-7,8-dihydroguanine

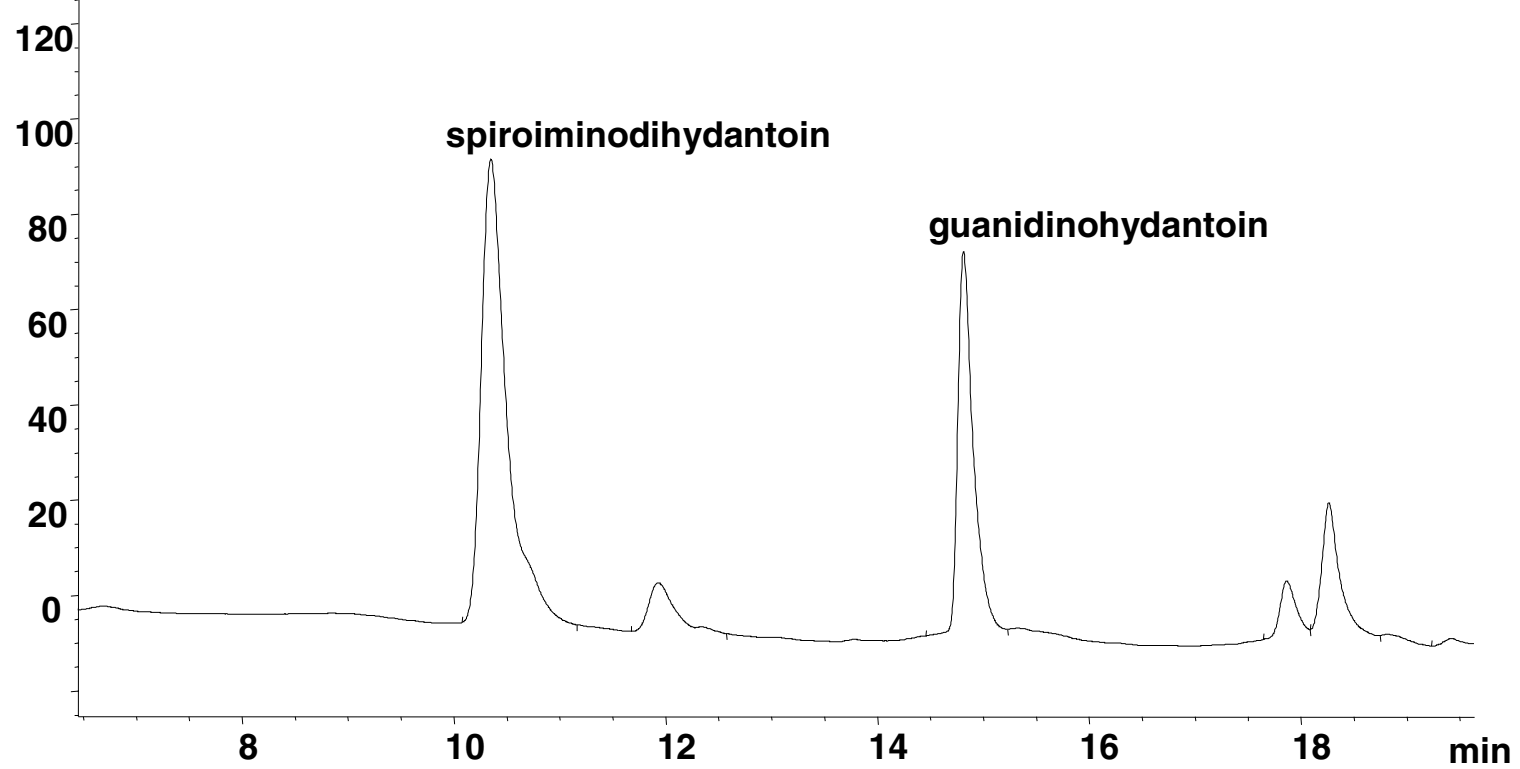


Oxidation of N9-Methyluric Acid (dotted line: without spiking of 1-methylSpd; solid line: with spiking of 1-methylSpd)

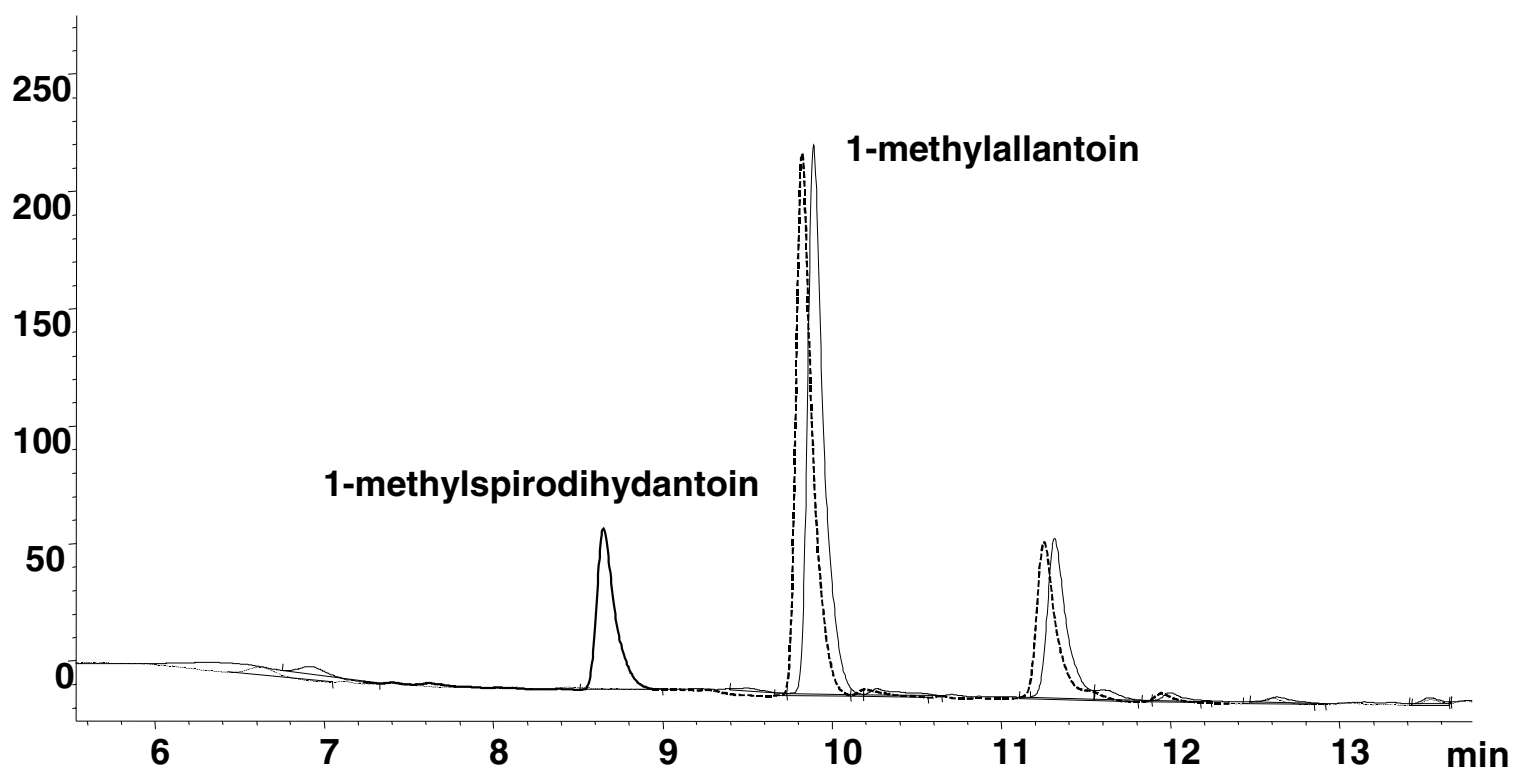

Oxidation of N7-Methyluric Acid

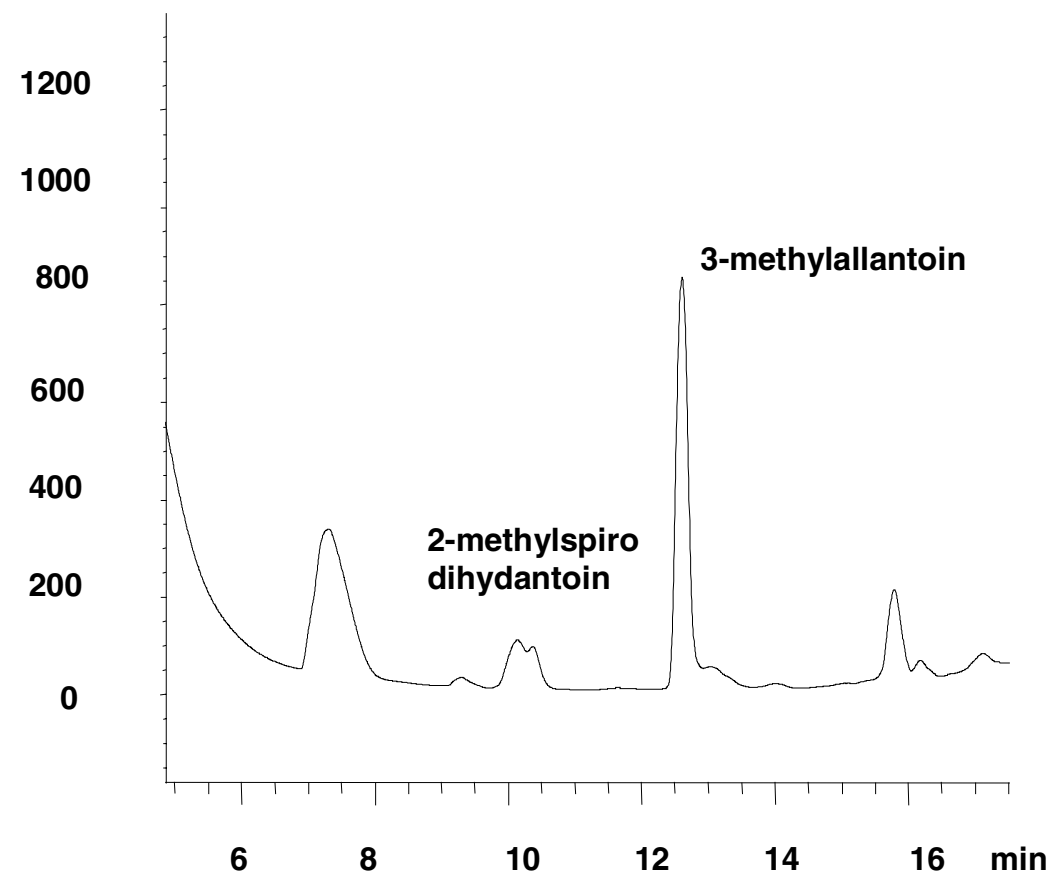


Decomposition of 5-Chloro-N7-methylisouric acid

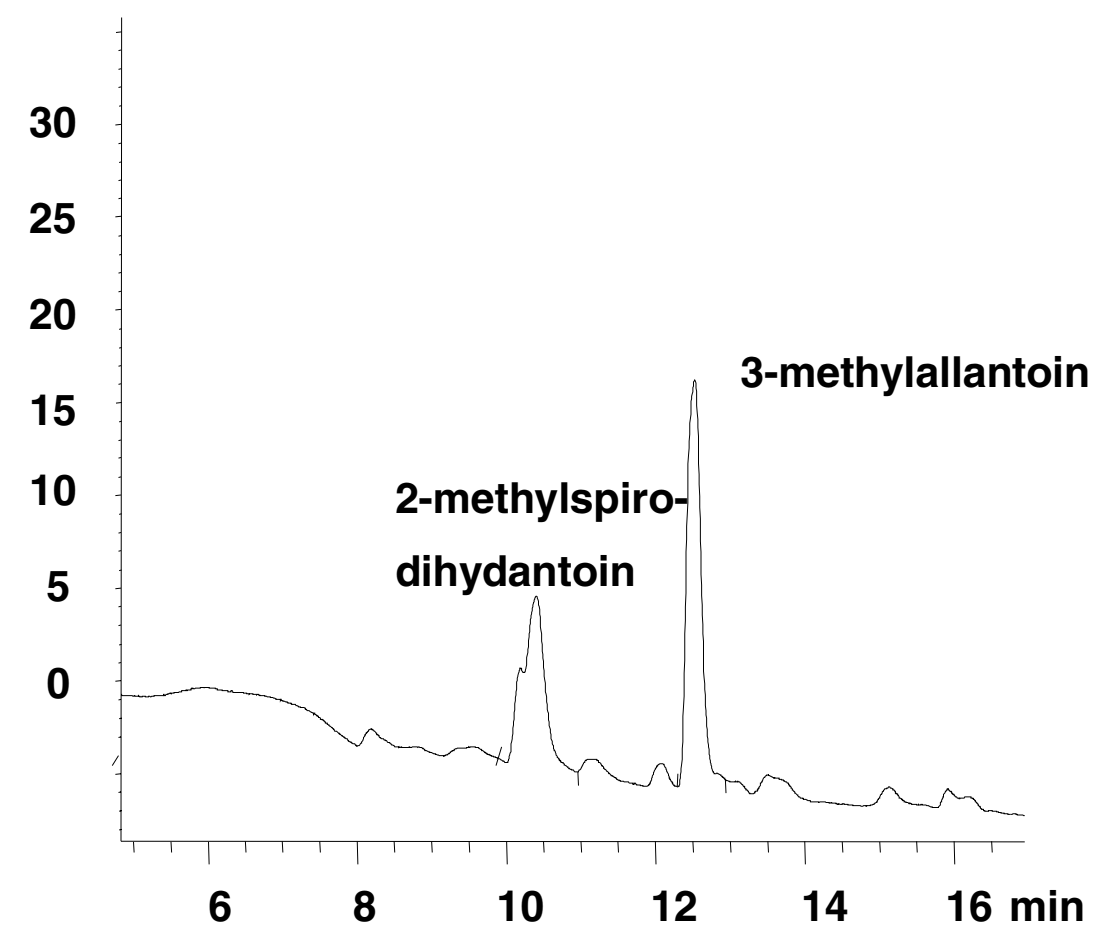


Selective Ion Monitoring Chromatograms of Detection of Spirodihydantoin with Labeled Spirodihydantoin as Internal Standard (A: positive ion mode; B: negative ion mode).
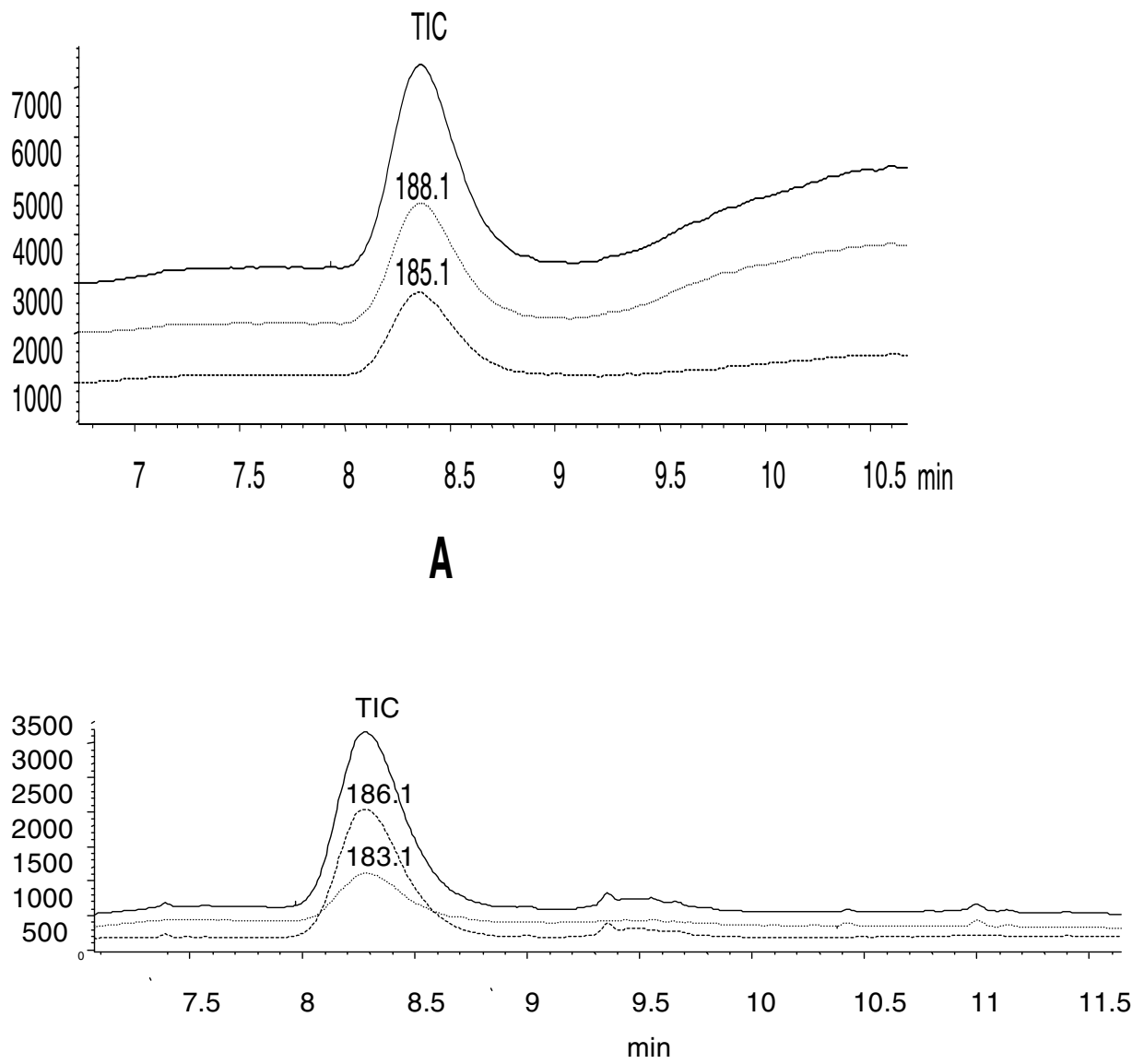

B 
Mass Spectra of Detection of ${ }^{18}$ O-Labeled Spirodihydantoin with Spirodihydantoin and Labeled Spirodihydantoin as Internal Standards

Formation of Spirodihydantoin in $\mathrm{H}_{2} \mathrm{O}$ with Labeled Spirodihydantoin as the Internal Standard

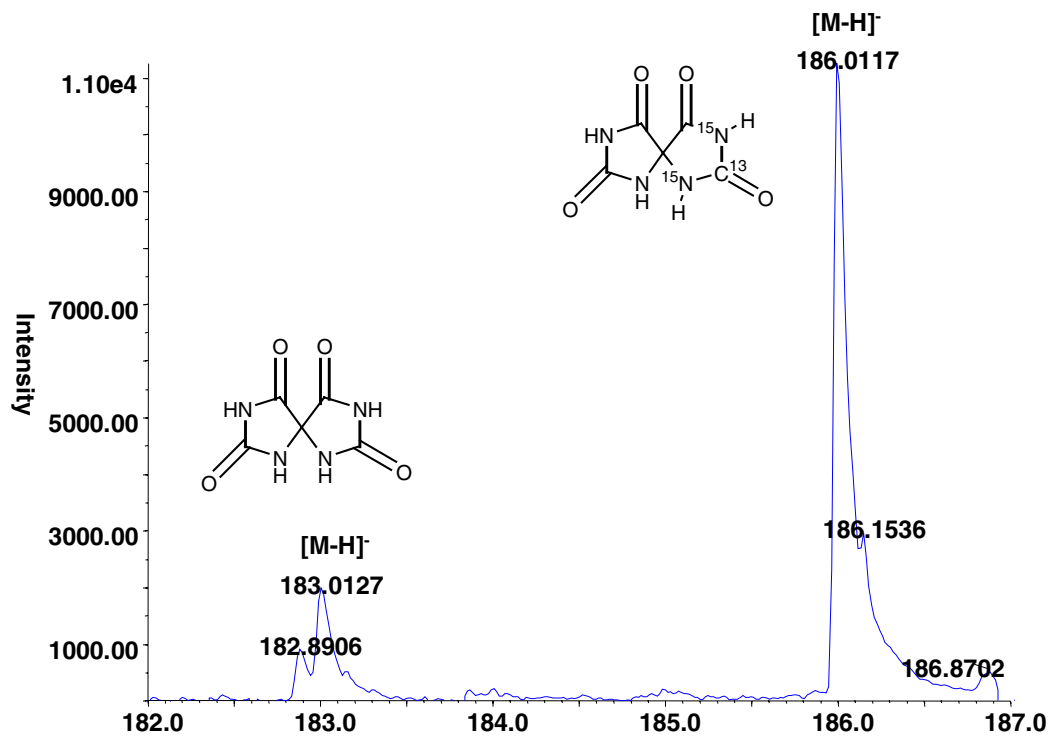

Formation of ${ }^{18} \mathrm{O}$-Labeled Spirodihydantoin in $\mathrm{H}_{2}^{18} \mathrm{O}$ with both Unlabeled and Labeled Spirodihydantoin as Internal Standards

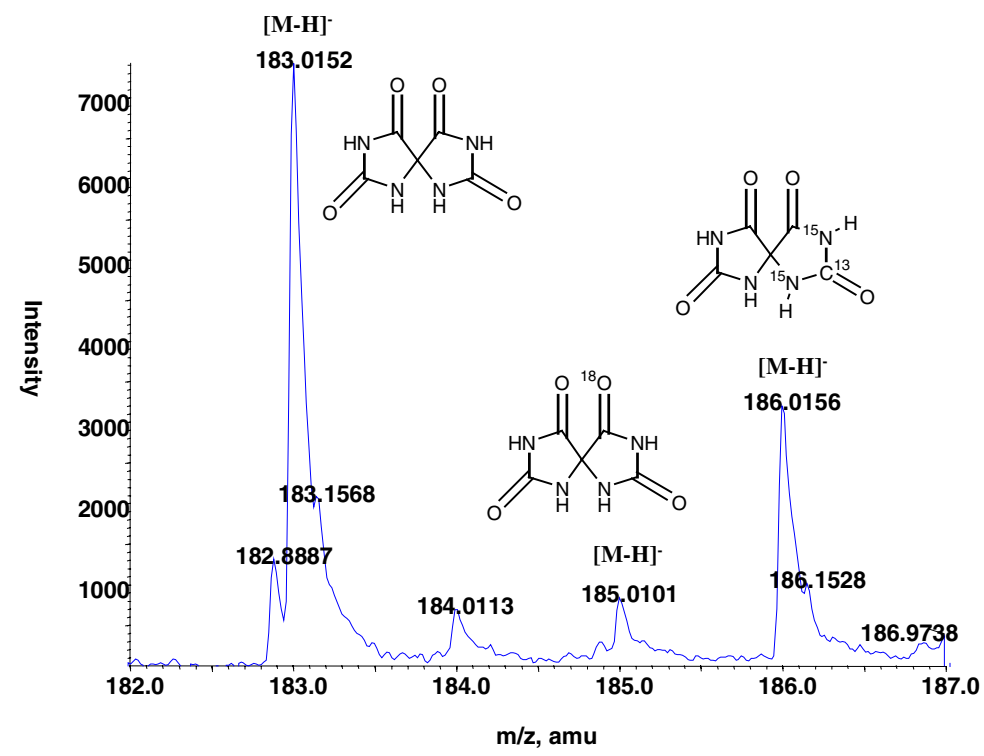


${ }^{13} \mathrm{C}$-NMR of Spirodihydantoin and 1-Methylspirodihydantoin

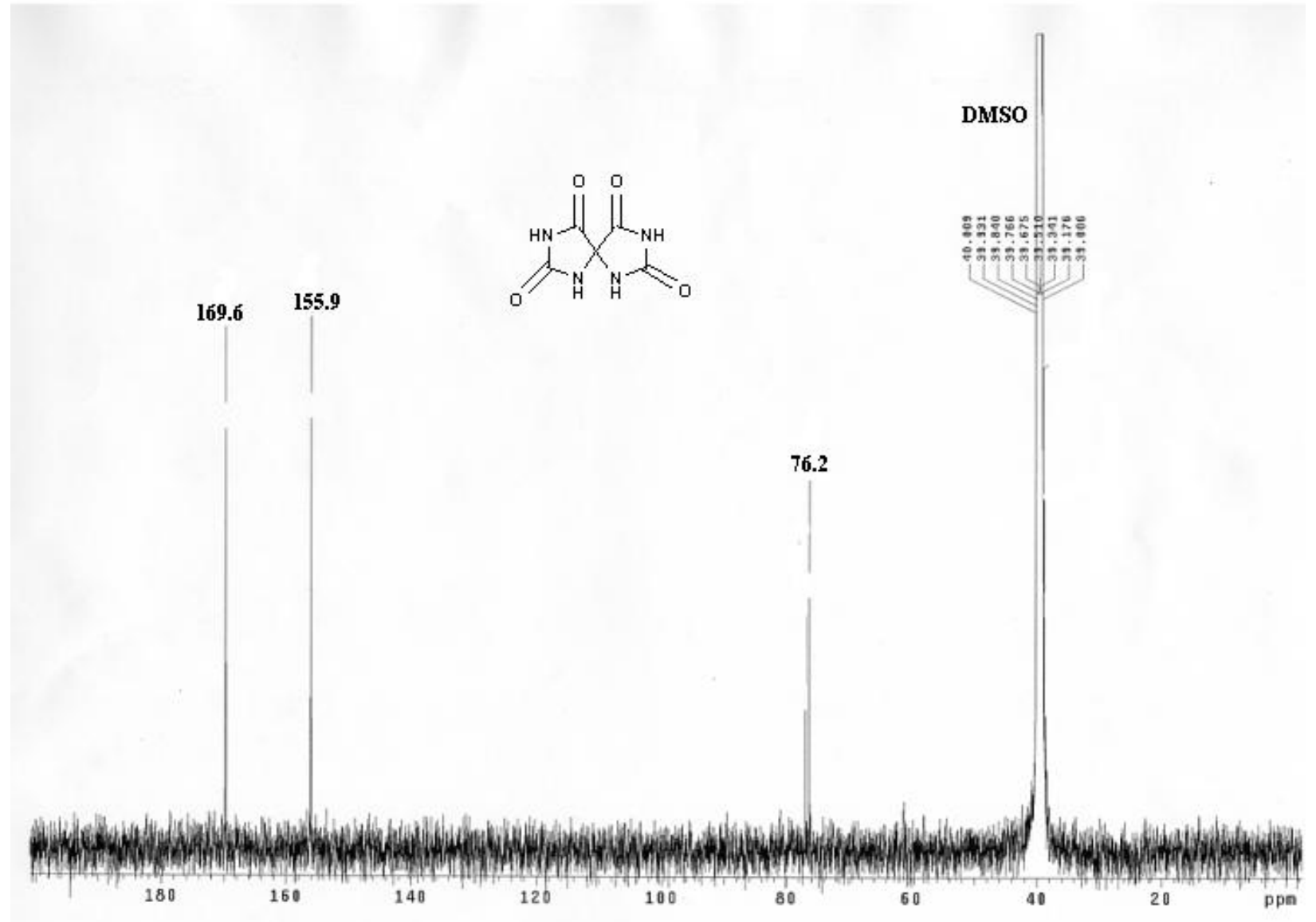




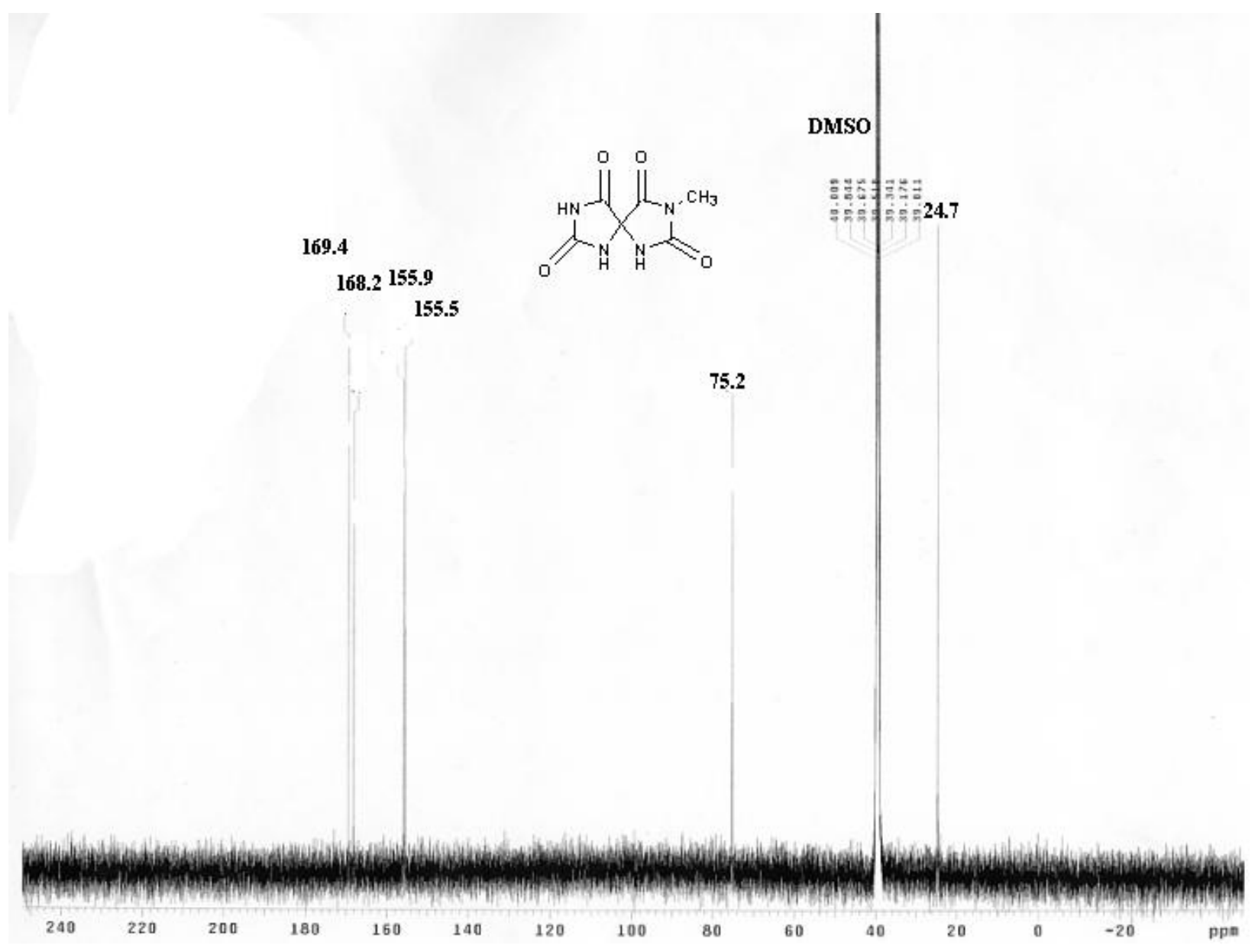


Scheme 1: ${ }^{18}$ O-Labeling Experiments and Decomposition of 5-Chloro-N7-methylisouric acid
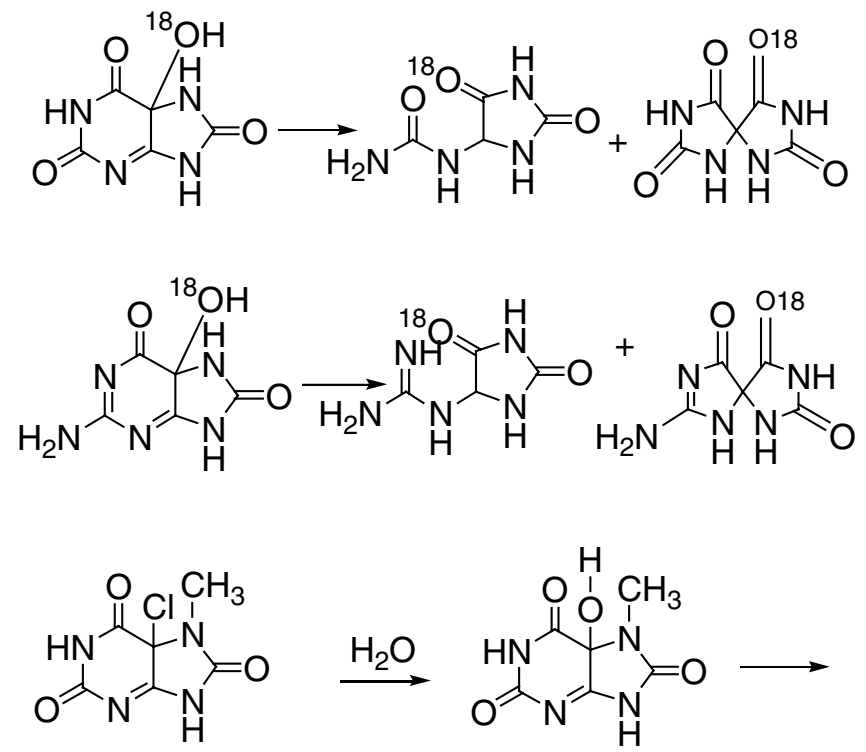<smiles>CN1C(=O)NC(NC(N)=O)C1=O</smiles><smiles>CN1C(=O)NC2(NC(=O)NC2=O)C1=O</smiles> 
Scheme 2: Decomposition of 5-OH-isourate and 5-OH-8-oxo-7,8-dihydroguanine

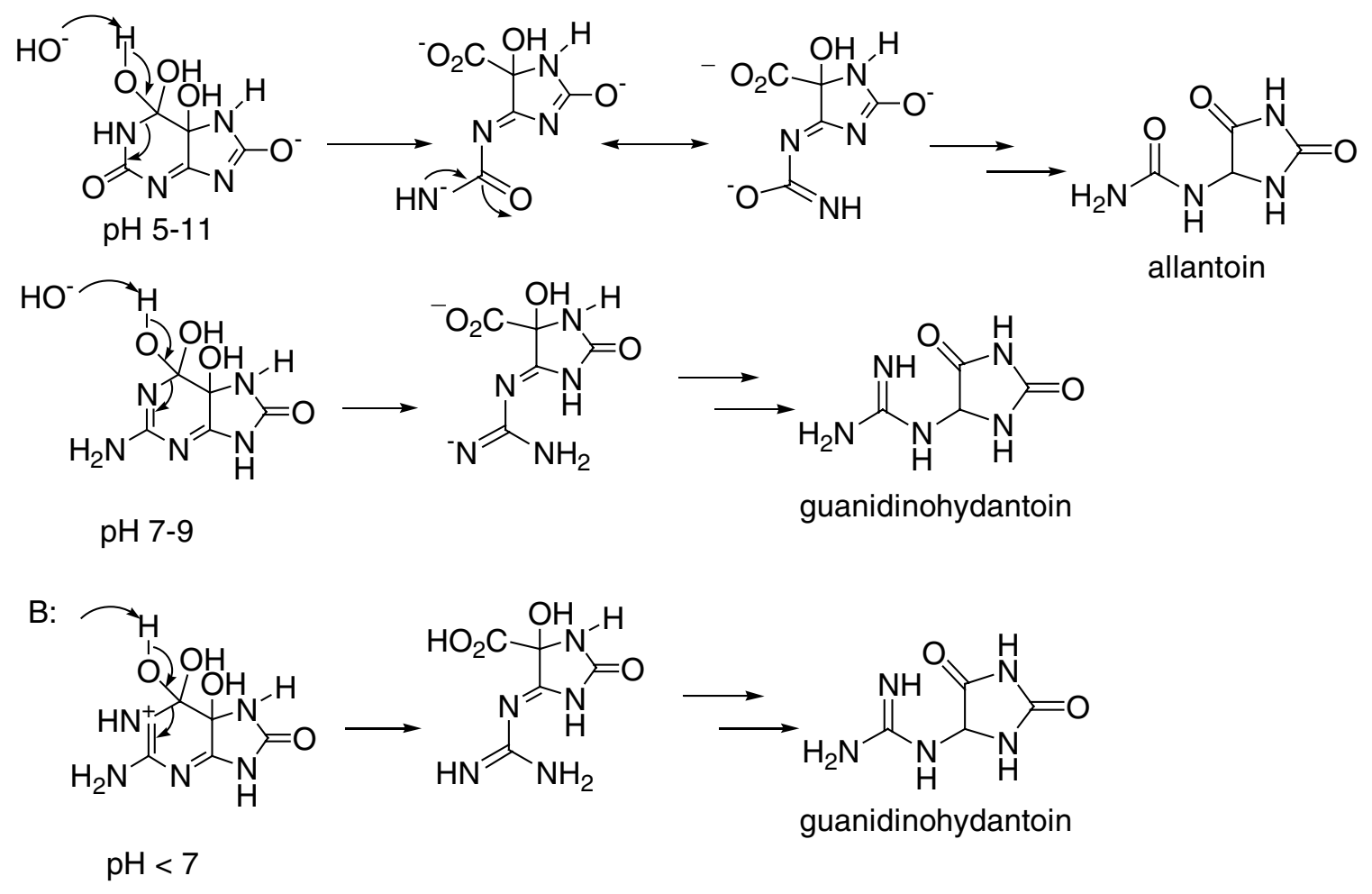


Physico-chemical Properties of Stable Analogs of 5-OH-isourate and 5-OH-8-oxo-7,8dihydroguanine<smiles>[R]C1CN=C2N=C(N)N=C([O-])C2(O)N1</smiles><smiles>[R6]c1cc2c(cc1[R5])N([R5])C1(NC(=O)N(C)C1=O)C(=O)N([R2])C2C(C)O</smiles><smiles>[R]c1cc2nc3c([O-])nc(=O)nc-3n([Al])c2cc1[R9]</smiles> 


\section{References}

1. Poje, M., Paulus, E. F., and Rocic, B. (1980) J. Org. Chem. 45, 65-68.

2. Luo, W., Muller, J. G., Rachlin, E. M., and Burrows, C. J. (2000) Org. Lett. 2, 613-616.

3. Kahn, K., Serfozo, P., and Tipton, P. A. (1997) J. Am. Chem. Soc. 119, 5435-5442.

4. Van der Vliet, A., Eiserich, J. P., Halliwell, B., and Cross, C. E. (1997) J. Biol. Chem. 272, 76177625.

5. Subramanian, P., Nguyen, N. T., Dryhurst, G., Hutzenlaub, W., and Pfleiderer, W. (1989) J. Electroanal. Chem. Interfacial Electrochem. 263, 353-371. 